\title{
Histological and ultrastructural studies on the effect of Cleome droserifolia plant from Sinai on the liver and kidney tissues of rats
}

\author{
Nahed Mohamed Mansour Emam \\ Biological and geological Department, Faculty of Education, \\ Suez Canal University. Ismailia Egypt.
}

\begin{abstract}
Sinai regions are characterized by the presence of large number of medicinal plants that are highly used in folk treatments but only a small number of these plants have received scientific and medical evaluation to assess their efficacy. Among these plants, Cleome droserifolia plant, which is commonly used in the Egyptian folk medicine for treatment of many diseases. The present study was planned to examine the safety of using an extract of Cleome droserifolia plant. This study focuses on the histopathological and ultrastructural changes induced by the plant extract in liver and kidney of the experimental rats. Cleome droserifolia treatment produced cellular swelling, cytoplasmic granulation with necrotic cells in addition to appearance of patches of depleted glycogen within the hepatic cytoplasm. The glomeruli were hypertrophied with thickening of Bowman's capsule and the renal tubules exhibited damaged epithelial lining cells in addition to the appearance of numerous lysosomes. Such changes in the present study may be due to the toxic effect or accumulation of one or more of the active pharmacological compounds of the plant in the liver or kidney tissues of the treated rats. It is recommended that future studies and chemical analytical techniques are required to separate and purify the main components from the plant responsible for safety and quality assurances for good practices of the plant.
\end{abstract}

Keywords: Cleome, droserifolia, liver, kidney, histological, ultrastructural

\section{Introduction}

The use of the medicinal plants for health started thousands years ago and is still part of the medical practice in China, Egypt, India and other developing countries. Modern pharmaceutical still contains at least $25 \%$ of drugs derived from plants (Thomas, 2000). Moreover, care must be taken when using medicinal herbs and plants, since many of them are potent may contain powerful combinations of chemicals and their chemistry is complex and some other plants are toxic. The toxicity is not only referred to the lethal effects, but also to minor body reactions such as allergy, irritation and sensitivity (Weiss and Fintelmann, 2000).

The Egyptian regions are characterized by the presence of a large number of medicinal plants and herbs of medicinal values and highly used in folk treatments. In Sinai, there are about thousand types of plants among which many types are used by patients in treating different diseases. These plants belong to above fifty families such as (Amaranthaceae, Cleomacea, Compositae, Capparaceae,.ect) according to Tackholm (1974); Rizk (1986); Boulos (1995, 1999) and Reda et al. (2000). So that Cleomace droserifolia (Samwa) from Sinai was chosen for this study,

It belongs to family Cleomacea or Capparaceae, which may be considered as very important herb and highly used in folk treatments in Sinai. Very few reports have been reported on the histopathological or ultrastructural or cytogenic effects of this plant.

The present study aims to elucidate the effects of this plant on the histopathological and ultrastructural 
changes of liver and kidney tissues of rats treated orally with Cleome droserifolia plant extract for three different periods.

According to Boulos (1999), genus Cleome was represented under family Capparaceae, or under the family Cleomacea. Plants of this family are herbs, shrubs or trees, sometimes woody climbers with alternate leaves. According to Tackholm (1974) and Boulos (1999) there are nine species of genus Cleome in Egypt including Cleome droserifolia (Forssk) Del.(as shown in the next figure), Cleome chrysantha Decnei.,Cleome scaposa DC., Cleome arabica L., Cleome brachycarba.,
Cleome hamburyana penzing, Cleome amblyocarpa., Cleome paradoxa., Cleome viscosa L. Folk medicine used Cleome species for treatment of many diseases and have antimicrobial activity (Sudhakar et al., 2006), analgesic, antipyretic, antiinflammatory activities (Narendhirakannan et al., 2006; Bose et al., 2007) and anticancer activities (Bala et al,. 2010).

Cleome droserifolia plant grows in different regions of North and South Sinai (Boulos, 1999 ; Reda et al., 2000) and has many different nomenclatures as El Samwa, Rem El-bard, Afeen and Mashta (by Arabic), and Frossk (by English).
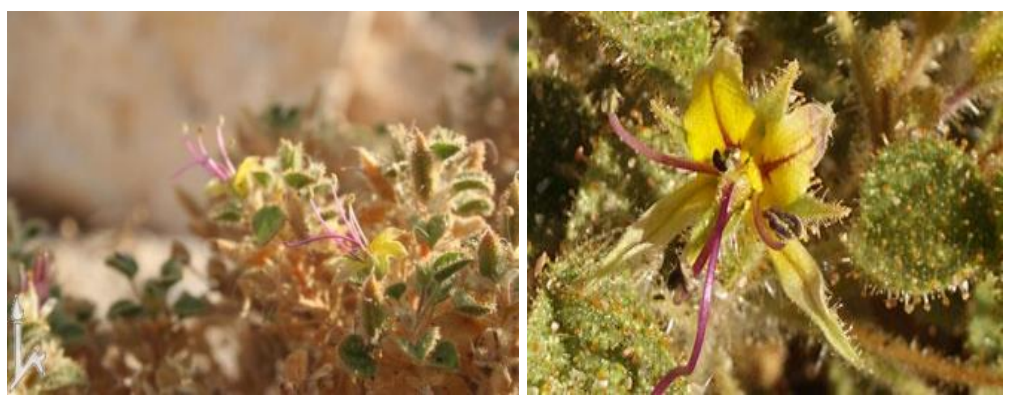
Synonymy $\quad=$ Roridula droserifolia Forssk. [Family: Roridulaceae]
= Cleome roridula [family: Capparacae]
$=$ Roridula arabica Roem. $[$ Roridulaceae $]$

\begin{abstract}
Cleome droserifolia has an immediate effect on abdominal and rheumatic pains, diabetes, inflammations and treatment snake and scorpion stings (Reda et al., 2000). In addition, Cleome droserifolia extracts has specific biological effects in improving the carbohydrate metabolism (Mikhail, 2000).
\end{abstract}

According to El Zorba (1993), the prolonged oral administration of alcoholic extract of Cleome droserifolia for 12 weeks showed hyperemic capillaries in the kidney tissues suggesting more blood supply to the kidney which may be responsible for diuresis. While in the liver only dilatation of blood vessels with karyomegalic nuclei as well as increased Kupffer cells were demonstrated. Other organs showed only hyperemia and dilation of vessels.
Devi et al. (2002) proved antidiarrheal potential activity of Cleome viscosa (Capparidaceae) in rats. Also, Williams et al. (2003) proved anti-bacterial, anti-fungal activities of Cleome viscose plant. Cleome droserifolia plant acts as antiobesity (Helal et al. 2002), hypoglycemic or antidiabetic plant (Helal et al., 2002; El Naggar et al., 2005; ElShenawy and Abdel-Nabi, 2006). Also, ElShenawy et al. (2006) reported the antioxidant and anti-schistosomiasis mansoni activity of Cleome droserifolia plant.

Abdel-Kader et al. (2009) proved the hepatoprotective properties of Cleome droserifolia plant against carbon tetrachloride induced liver injury through biochemical parameters and histopathological changes. The authors also isolated the hepatoprotective constituents 
from the plant whereas the fractions afforded three guaiane sesquiterpenes (buchariol; teucladiol; daucosterol) and three known flavonoid derivatives. Also Gupta and Dixit (2009) proved the hepatoprotective activity of ethanolic extract of Cleome viscosa (Capparidaceae) against carbon tetrachloride induced hepatotoxicity in experimental animal models.

El-Askary (2005) isolated a new diacetyl triterpene lactone, drosericarpone from the hexane extract of the herb Cleome droserifolia, together with buchariol and stigmasterol glucoside. Bouriche and Arnhold (2010) reported that the leaves of Cleome arabica (Capparaceae), which contains a number of glucosylated and rhamnosylated flavonols, possess antiinflammatory activity and are used for the treatment of abdominal and rheumatic pains. Aboushoer et al. (2010) isolated four new sesquiterpene derivatives from the aerial parts of Cleome droserifolia, in addition, a new dolabellane diterpene derivative and two known flavonoid derivatives, pinocembrin and quercetin.

This study aims to evaluate the histopathological and ultrastructural changes induced by Cleome droserifolia plant extract in the liver and kidney of the experimental animals.

\section{Materials and methods:}

\section{Plant materials}

The herb Samwa or Cleome droserifolia (Family: Cleomacea or Capparaceae ) was collected from South of Sinai, Egypt. The plant was dried in dark at room temperature for about two weeks. The whole plant was ground and weighed for preparation of plant extracts. The powder of the whole plant was refluxed with $70 \%$ methanolic alcohol for four days. The alcoholic extract obtained after filtration was evaporated at temperature not exceeding $50^{\circ} \mathrm{C}$ by rotatory evaporator apparatus. The residue was then weighed and suspended in distilled water according to the method of Ammar et al. (1993) for preparation of the required dose $(100 \mu \mathrm{g} / \mathrm{g}$ body weight) according to Zaohkouk et al.(2001).

Experimental animals

The present study was carried out on adult, normal and healthy male albino rats (140-160 g body weight) supplied from Helwan laboratory farms of the Egyptian Organization for Vaccine and Biological Preparations. The animals were weighted, marked and housed 5 rat per cage under regular periods of 12 hours dark, and 12 hours light at room temperature. The floors of the metal cages were covered by a dry wood flakes changed daily and washed 4times weekly. Rats were fed on standard rodent pellet diet manufactured by Egyptian Company for Oil and Soap and provided with water.

\section{Experimental groups:-}

The animals were divided into four main groups as follow:-

\section{1-Control groups (I)}

The first group consists of 30 rats used as control that received distilled water through gastric intubation daily for 15, 30 and 45 days. So that this group subdivided into three subgroups, each one composed of 10 rats.

\section{2-plant treated group (II)}

The second group consists of 30 rats that treated with the plant extract of Cleome droserifolia, so that this group was subdivided into three subgroups, each one composed of 10 rats. The three subgroups received methanolic extract of the plant through gastric intubation (stomach tube) daily for 15,30 and 45 days at concentrations of $100 \mu \mathrm{g} / \mathrm{g}$ body weight.

\section{$\underline{\text { Histological studies }}$}

By the end of each experiment, rats were anesthetized by ether and abdominally dissected. Samples from the liver and kidney tissues were taken out and washed in physiological saline solution $(0.9 \%$ $\mathrm{NaCl})$ after which the required parts were fixed in $10 \%$ formal saline or Bouin's fluid for 24 hours followed by post fixation in 
running water or several changes of $70 \%$ ethyl alcohol respectively.

The specimens were preserved in $70 \%$ ethyl alcohol, then dehydrated in ascending series of ethyl alcohol, cleared in terpinol and embedded in paraffin wax. Sections of 5 microns thick were mounted on clean glass slides and stained with Hematoxylin and Eosin (Drury \& Wallington, 1980). The prepared slides were microscopically examined and photographs were taken to various sections by using Carl Zeiss Axiolabre light microscope in Suez Canal University Center for Environmental Studies and Consultation.

\section{$\underline{\text { Ultrastructural studies }}$}

Small pieces of $1 \mathrm{~mm}$ of liver and kidney tissues were obtained from all dissected animals. The specimens were fixed in a mixture of (4:1) $25 \%$ glutaraldehyde / $40 \%$ formaldehyde at $\mathrm{pH}$ 7.4 at room temperature for 4 hours then rinsed twice in $0.1 \mathrm{M}$ phosphate buffer (15 minutes for each) according to Karnofsky (1965). Specimens were post fixed in $2.0 \%$ buffered osmic acid for half an hour at $4{ }^{\circ} \mathrm{C}$, and then washed twice in phosphate buffer for $30 \mathrm{~min}$.

The materials were then dehydrated in ascending series of ethyl alcohol. Specimens were then infiltrated at room temperature in a mixture of low viscosity embedding medium (Spurr) and absolute alcohol in proportions of 1:1 for 1 hour, 2:1 for 2 hour and 3:1 for 3 hour. Materials were then infiltrated in pure Spurr for 3 hours (Hayat, 1989). By using plastic mould materials, the samples were embedded in Spur. Materials were polymerised at $60^{\circ} \mathrm{C}$ for $6-18$ hours. Blocks were trimmed under the binocular microscope of Ultra cut Reichert Jung Ultmicrotome. Semi-thin sections of 1micron thickness were obtained with the aid of glass knives.

Semi-thin sections were stained by toludine blue and examined with the light microscope for general orientation. Specimens were then retimed to the selected region and ultrathin sections of 60 $\mathrm{nm}$ thickness were cut and picked up on copper grids. Sections mounted on grids were double stained by using uranyl acetate and lead citrate (Reynolds, 1963).

\section{Results}

\section{Effects of Cleome droserifolia extract on}

\section{the liver}

\section{The histological study}

\section{I-Control group}

The liver of rats is formed of hepatic lobes each consists of a number of classical polygonal hepatic lobules separated from each other by incomplete layer of connective tissue that contain portal tracts. Hepatocytes are polygonal in shape with rounded nuclei (Fig. 1), while some cells are binucleated. Blood sinusoids originate at the lobule margins and course between the hepatic cords to converge upon the central vein. The sinusoidal lining cells include the sinusoidal endothelial cells with flat dark stained nuclei and Kupffer cells which are large phagocytic cells with ovoid nuclei

\section{II-Plant treated group}

\section{A-Fifteen days sub-group:}

Oral administrations of Cleome droserifolia extract (100 $\mu \mathrm{g} / \mathrm{g}$ b. wt.) for 15 days showed slight cellular swelling with the cytoplasmic granulation (Figs. 2, 3). Cellular infiltrations were appeared in between the swollen hepatocytes (Fig. 2) and around the dilated central vein (Fig. 3). Most of the nuclei are in normal appearance (Figs 2, 3).

\section{B-Thirty days sub-group:}

By 30 days of Cleome droserifolia extract treatment, most of the hepatic cells are severely swollen, damaged with variable degree of cytoplasmic lysis (Fig. 4). Moreover, there are numerous necrotic cells with pyknotic nuclei and hypertrophied Kupffer cells and haemolysed RBCs inside the blood vessels (Fig. 5). There are large areas of completely degenerated and disappeared hepatocytes 


\section{Nahed Mohamed}

replaced by haemolysed blood cells (Fig. 5). Also there are numerous inflammatory cells in the portal area (Fig. 4) and in between the hepatic cells (Fig. 5). Numerous pyknotic nuclei were also observed.

\section{C-Forty five days sub-group:}

Liver sections obtained from this sub-group revealed similar previous stage but with increased severity of cellular swelling and cellular damage (Figs. 6, 7). Moreover, severely necrotic cells with pyknotic nuclei, hypertrophied Kupffer cells were clearly appeared. There were large areas of inflammatory cells in the portal areas with haemolysed RBCs (Fig.7). Also, variable degrees of the cytoplasmic lysis is common and some of hepatocytes lost their nuclei (Fig. 6)
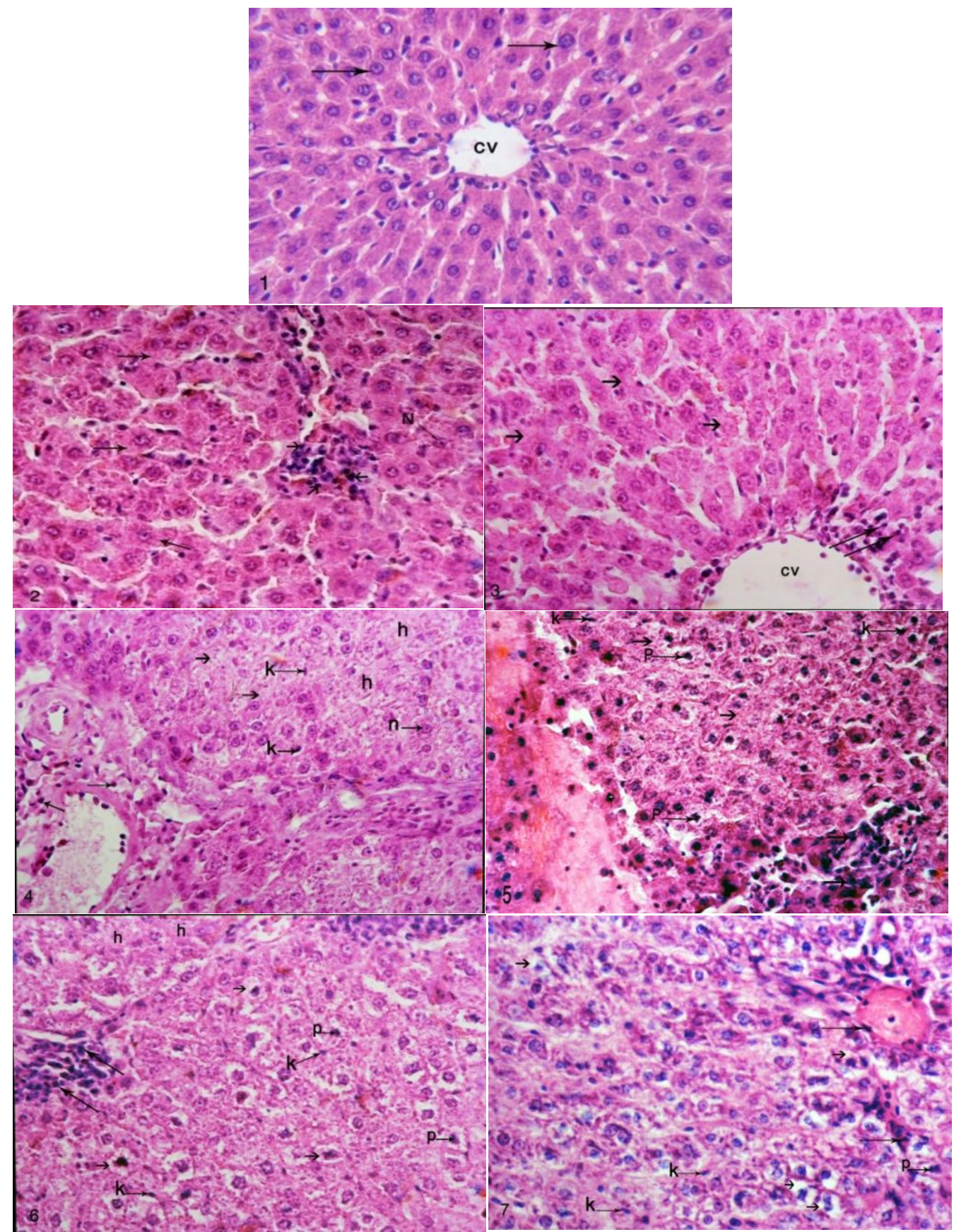
Figure (1): Liver section of a control rat showing normal hepatic architecture with hepatic cords radiating around a central vein (cv) and rounded to oval normal nuclei (arrows). (H\&E, X400).

Figure (2): Slightly cellular swelling in liver section obtained from a rat treated with Cleome droserifolia extract for 15 days. The hepatocytes show cytoplasmic granulation (long arrows) but mostly normal nuclei. Note the presence of numerous inflammatory cells in between the hepatocytes (short arrows). (H\&E, X400).

Figure (3): Liver section from a rat treated with Cleome droserifolia extract for 15 days showing cytoplasmic granulation (short arrows), dilated central vein (cv) and appearance of numerous inflammatory cells around the central vein (long arrows). (H\&E, X400).

Figure (4): Liver section of a rat treated with Cleome droserifolia extract for 30 days showing cellular swelling, cytoplasmic granulation and vacuolization (short arrows) but with some normal nuclei (n). Note portal areas invaded with numerous inflammatory cells (long arrows), activated Kupffer cells (k). Some of damaged hepatocytes lost their nuclei (h). (H\&E, X400).

Figure (5): Intensively swollen, necrotic hepatocytes suffering from cytoplasmic granulation (short arrows) after 30 days of Cleome droserifolia extract treatment. Note the appearance of numerous lymphocytes (long arrows) in between the necrotic hepatocytes, pyknotic nuclei (p) and hypertrophied Kupffer cells (k). (H\&E, X400).

Figure (6): Liver section from a rat with Cleome droserifolia extract for 45 days showing severe hepatic cellular swelling and cellular necrosis (short arrows) with pyknotic nuclei (p) and degenerated cytoplasm. Note cellular infiltration in between the hepatocytes (long arrows), hypertrophied Kupffer cells (k). Some of damaged hepatocytes lost their nuclei (h). (H\&E, X400).

Figure (7): Ballooning of hepatocytes and cellular damage (short arrows) together with appearance of pyknotic (p) nuclei in liver section after 45 days of Cleome droserifolia extract treatment. The portal area invaded with numerous inflammatory cells with haemolysed RBCs (long arrows). Note hypertrophied Kupffer cells (k). (H\&E, X400).

\section{The ultrastructural study}

\section{I-The control group}

The ultrastructural examination of the control liver sections demonstrated polyhedral hepatocytes with sinusoidal spaces in between. Each hepatocyte is bounded by a well demarcated plasma membrane (Fig. 8) and contains a rounded prominent nucleus, however some cells are binucleated. The hepatic cytoplasm has a granular appearance and contains a variety of different cell organelles. The blood sinusoids lie in between the hepatocytes, lined by thin irregular wall, which is made up of two types of cells, endothelial and Kupffer cells.

\section{II- Plant treated group}

Numerous pathological changes were recorded in the ultrastructure of the liver cells obtained from rats after 15, 30, 45 days of treatments with Cleome droserifolia extract. These changes increased in their severity especially at 45 days of treatment. The changes included the presence of patches of depleted glycogen within the cytoplasm (Figs.9, 10, 11, 12, and 14).

The hepatic cytoplasm contained mitochondria with different electron density ranging from moderate (Figs. 9, 10) to highly condensed ones (Fig. 15). Swollen mitochondria (Fig. 13) and darkly stained mitochondria with fused membranes (Fig. 15) were also appeared in most hepatic cells especially at 30,45 days of plant extract treatments. The rough endoplasmic reticulum revealed dilated cisternae to which masses of aggregated ribosomes were externally attached (Figs. 10, 12, 13). Also in most hepatic cells, the cisternal structures of the endoplasmic reticulum were mostly fragmented and lost their parallel arrangement especially at 45 days of the extract treatment (Fig. 15). Ribosomes were present as free small 
electron dense granules scattered in the cytoplasm (Figs. 11, 13).

The hepatic cell cytoplasm also showed numerous scattered lysosomes with a spherical shape limited by thin membranes and contained electron dense core especially at 45 days of the extract treatment (Figs.14, 15, 16). Thickened nuclear membranes were clearly appeared in most cells (Figs. 9, 17).

At 45 days of the extract treatment, most of cell organelles were degenerated

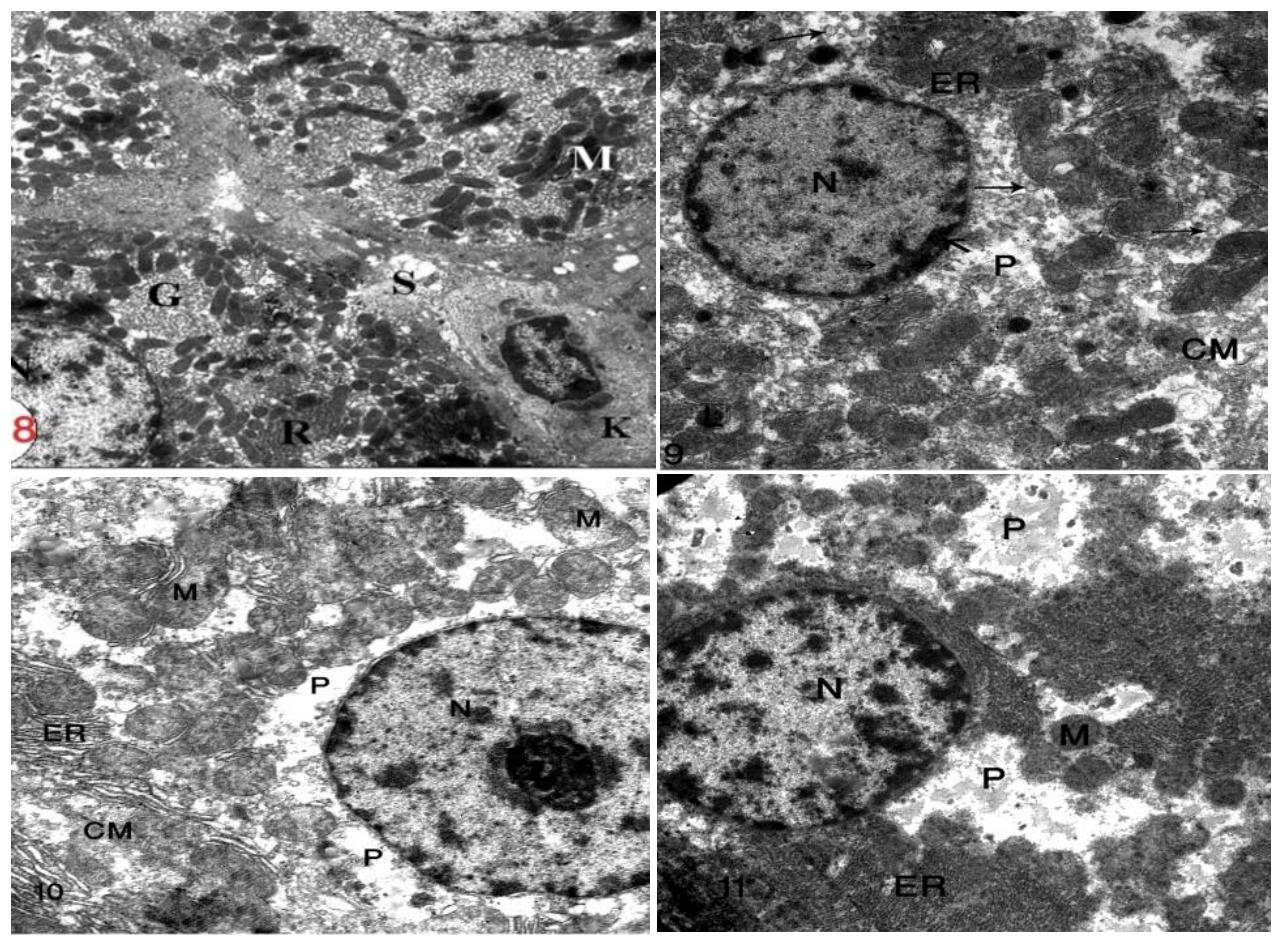

Figure (8): Hepatocytes around blood sinusoid (S) in liver section of a normal rat. The hepatic cytoplasm shows stored glycogen granules $(\mathrm{G})$, small and numerous mitochondria $(\mathrm{M})$ with electron dense materials, parallel cisternea of rough endoplasmic reticulum $(\mathrm{R})$ and rounded nuclei. Note: Kupffer cells $(\mathrm{K})$ in the sinusoidal space (S). (X5293).

Figure (9): Part of a hepatocyte from a rat treated with Cleome droserifolia extract for 15 days revealing slightly dilated rough endoplasmic reticulum (ER), lysosomes (L), small vesicles (long arrows) and numerous small patches of glycogen depletion (p). The nucleus (n) with thickened, irregular nuclear membranes (short arrows). CM: Cell membrane. (X10587).

Figure (10): An electron micrograph of a liver section of a rat treated with Cleome droserifolia extract for 15 days revealing slightly dilated endoplasmic reticulum (ER), patches of glycogen depletion (p), swollen mitochondria $(\mathrm{M})$ packed with moderate electron dense materials. $\mathrm{N}$ : Nucleus CM: Cell membrane. (X10587)

Figure (11): Part of a hepatocyte from a rat treated with Cleome droserifolia extract for 30 days revealing empty looking spaces of depleted glycogen (p), mitochondria (M), dilated rough endoplasmic reticulum (ER). N: Nucleus. (X10587). and lost in many cells (Figs. 14, 15, 16) and $(14,15,16)$. The cell membranes of hepatocytes were intact in most cells (Figs. spaces appeared to contain some scattered electron lucent materials and some vacuoles cells showed damaged nuclei and degenerated cytoplasm (Fig. 17). their normal appearance, and the sinusoidal 


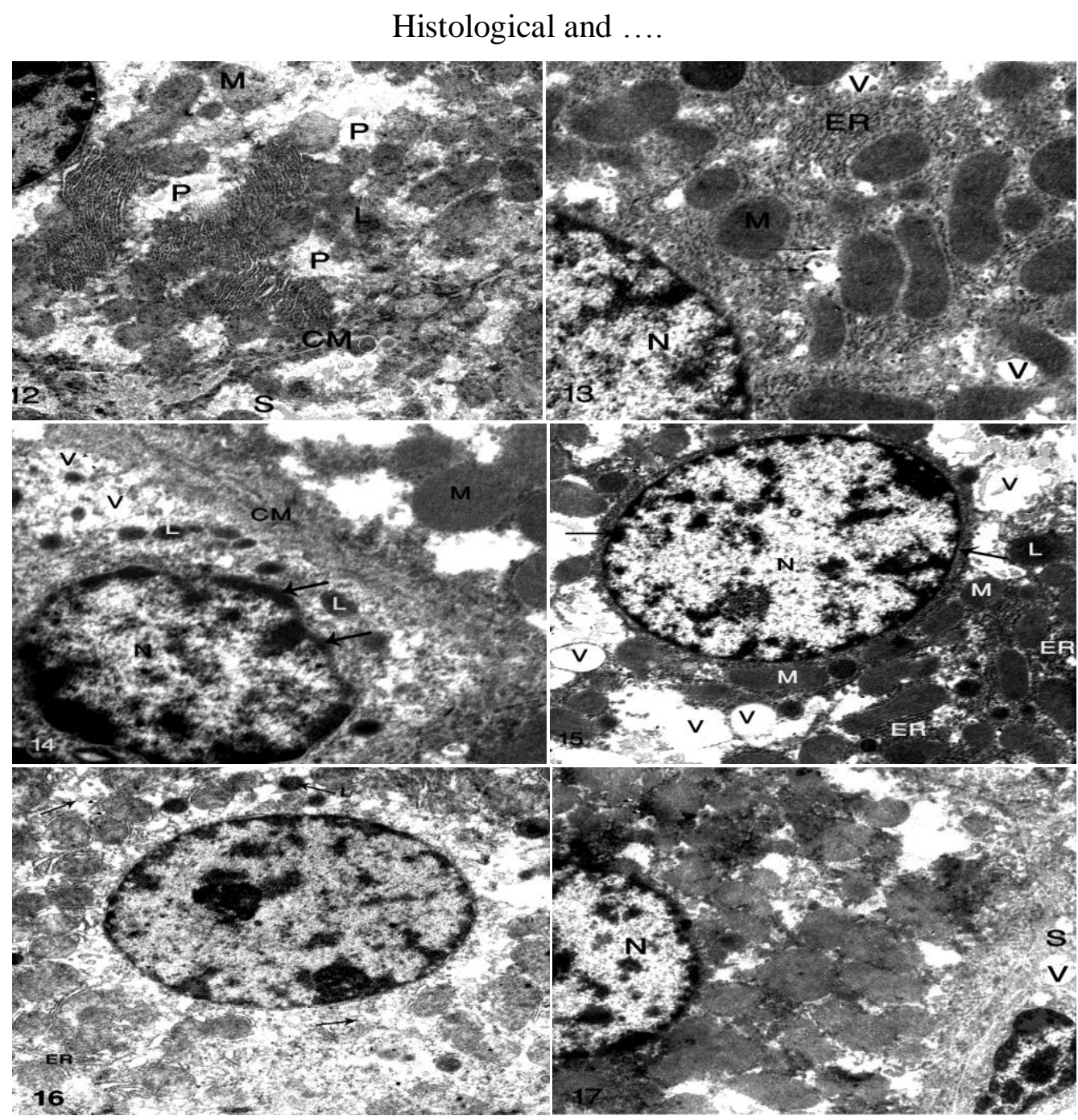

Figure (12): Liver section of a rat treated with Cleome droserifolia extract for 30 days showing numerous irregular patches (p) with electron transparent appearance, swollen mitochondria with moderately dense materials (M), lysosomes (L). CM: Cell membrane between two neighboring hepatocytes, N: Nucleus. S: Sinusoidal spaces. (X10587).

Figure (13): Part of a hepatocyte from a rat treated with Cleome droserifolia extract for 30 days revealing condensed swollen mitochondria $(\mathrm{M})$, dilated rough endoplasmic reticulum (ER), vacuoles (V), ribosomes (arrows) and a nucleus $(\mathrm{N})$ with thickened and fused nuclear membranes. (X21173).

Figure (14): An electron micrograph of a liver cell from a rat treated with Cleome droserifolia extract for 45 days showing numerous lysosomes (L), numerous vacuoles (V), mitochondria (M), disorganized cytoplasm and degenerated cell organelles. The nucleus $(\mathrm{N})$ appeared with thickened, irregular and fused nuclear membranes (arrows). CM: Cell membrane. (X21173).

Figure (15): Part of a hepatocyte from a rat treated with Cleome droserifolia extract for 45 days revealing highly condensed mitochondria $(\mathrm{M})$, numerous scattered lysosomes $(\mathrm{L})$, numerous vacuoles $(\mathrm{V})$, dilated rough endoplasmic reticulum (ER) but the nucleus $(\mathrm{N})$ appeared with double membranes (arrows). (X10587).

Figure (16): An electron micrograph of a a hepatocyte from a rat treated with Cleome droserifolia extract for 45 days revealing loss of the cytoplasm electron density and degenerated cell organelles, swollen endoplasmic reticulum (ER), lysosomes (L), numerous vesicles (arrows). (X10587).

Figure (17): Hepatic cell from a rat treated with Cleome droserifolia extract for 45 days revealing highly swollen mitochondria (M) packed with electron dense materials. The sinusoidal space (S) is lined by damaged wall and contained vacuoles (V) and abnormal nucleus of the sinusoidal epithelial cells with densely stained and marginated heterochromatin. (X10587). 
Effects of Cleome droserifolia extract on

the kidney

\section{The histological study}

\section{I-Control group}

The renal tissues in normal rats consist of both the cortex and the medulla. The most striking feature of the cortex is the presence of numerous spherical renal corpuscles as well as proximal and distal convoluted tubules (Fig. 18). The proximal convoluted tubules are the most common in the cortex and have a slightly larger diameter than the distal tubules. The lumen of the proximal tubules is often star-shaped due to the presence of brush borders, while the lumen of the distal tubule is rather extensive and widen.

\section{II-Plant treated group}

\section{A-Fifteen days sub-group}

The renal tissues obtained from rats treated with Cleome droserifolia extract for 15 days showed hypertrophied glomeruli (Fig. 20) or atrophied glomeruli with wide Bowman's space (Fig. 19). The epithelial lining cells of the distal convoluted tubules were degenerated (Figs. 19, 20). The cytoplasm of the tubules appeared with cytoplasmic vacuolization (Figs.19, 20). The nuclei appeared in normal appearance (Fig. 20) intermixed with very few deeply ones. Moreover, thickened and elongated arterial wall were clearly appeared (Fig.19)

\section{B-Thirty days sub-group}

The kidney tissues obtained after 30 days of administration of the plant extract revealed fragmented glomeruli or atrophied glomeruli with wide Bowman's space (Fig. 22). The renal tubules appeared with cellular swelling and lined by ruptured epithelium with vacuolated cytoplasm (Fig. 21). Also highly thickened arterial walls with elongated endothelial lining cells and the vein with dilated wall contained haemolysed RBCs were commonly appeared as shown in figure (22). Moreover, there are some intertubular inflammatory invasions at certain areas of the tissues (Figs.21, 22).

\section{C-Forty five days sub-group}

Investigation of the renal tissues obtained at this stage showed hypertrophied with degenerated cells of it and absence of Bowman's spaces (Fig. 23) or lobulated glomeruli with signs of mesangiolysis (Fig. 24). The renal tubules were severely damaged and exhibited intensive cellular swelling (Figs. 23, 24). The tubules appeared to contain completely damaged epithelium and their lumen appeared to contain cellular remnants (Fig. 23). The renal tubules also exhibited disturbed architecture with bizarre arrangement and severe necrobiotic changes (Figs. 23, 24). Most of the nuclei were pyknotic.

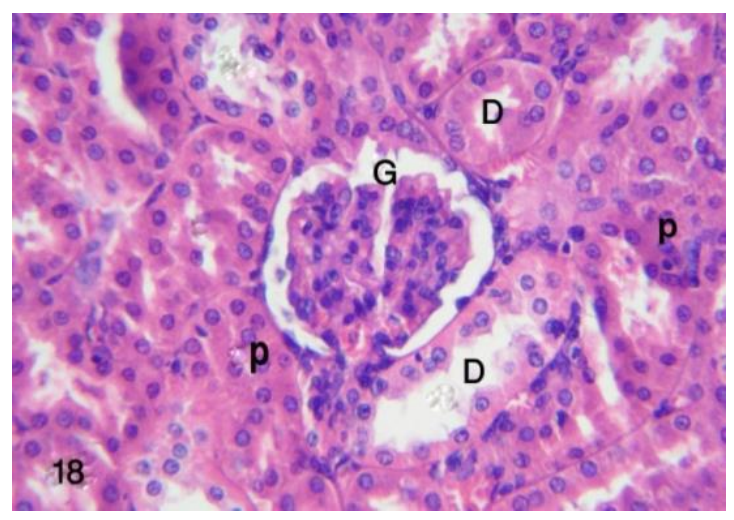

Figure (18): Transverse section in the kidney cortex of a control rat showing normal renal architecture of the renal corpuscles and renal tubules. The normal glomeruli (G), distal tubules (D) and proximal tubules (P) were clearly appeared. (H\&E, X400). 


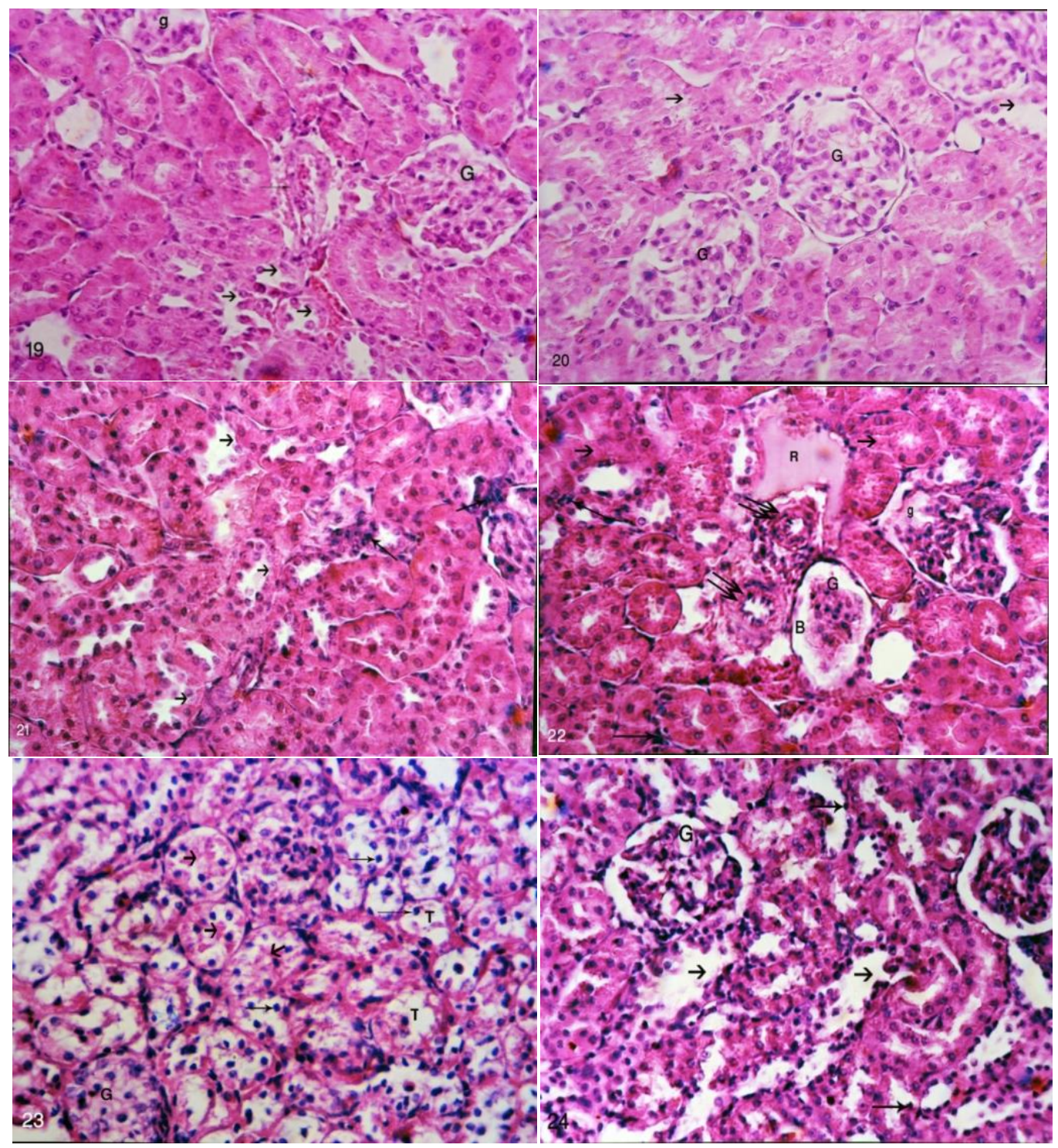

Figure (19): Kidney cortex from a rat treated with Cleome droserifolia extract for 15 days showing thickened and elongated arterial wall (long arrow), signs of degeneration in some epithelial cells of distal tubules (short arrows), atrophied glomerulus (g). G: Glomerulus, (H\&E, X400).

Figure (20): Kidney section obtained from a rat treated with Cleome droserifolia extract for 15 days showing hypertrophied glomeruli (G). Note damaged epithelial cells of the distal convoluted tubules (arrows). (H\&E, X400).

Figure (21): Section of the kidney from a rat treated Cleome droserifolia extract for 30 days showing cellular swelling and cytoplsmic vacuolization, ruptured epithelial cells of some distal convoluted tubules (short arrows) and the intertubular inflammatory invasion (long arrows).(H\&E, X400).

Figure (22): Histopathological changes of kidney section from a rat treated Cleome droserifolia extract for 30 days with intensive cellular swelling (short arrows), atrophied glomerulus $(\mathrm{G})$ with wide Bowman's spaces (B) or fragmented ones (g). Note highly thickened arterial walls (doubled long arrows) with elongated endothelial lining of them, dilated and corrugated wall of the vein which contained haemolysed RBCs (R) and numerous inflammatory cells in the intertubular spaces (long arrows). (H\&E, X400).

Figure (23): Severely damaged tubular epithelial cells scattered pyknotic nuclei (long arrows) in a rat treated with Cleome droserifolia extract for 45 days. The tubular lumina appeared with remnants of damaged cells and cell debris (short arrows). Note hypertrophied glomeruli (G) with degenerated cells of it and absence of Bowman's spaces. Renal tubules (T) lost their normal architecture. (H\&E, X400). 
Figure (24): Most renal tubules showed disturbed architecture with bizarre arrangement (short arrows) and lined by epithelial cells suffering from necrobiotic changes with pyknotic nuclei (long arrows) in a rat treated with Cleome droserifolia extract for 45 days. Note lobulated glomeruli (G) with signs of mesangiolysis. (H\&E, X400).

\section{The ultrastructural studies}

\section{I-The control group}

Electron microscopic examinations of control kidney sections revealed the typical ultrastructure of the nephron with its two main parts, the renal corpuscles and the renal tubules.

The renal corpuscle (Fig. 25) consists a tuft of glomerular capillaries enclosed within a double layered Bowman's capsule with a narrow slit like urinary space in between the outer (parietal layer) and the inner (visceral layer). The proximal convoluted tubules (Fig. 26) commence at the urinary pole of the renal corpuscles lined by cuboidal to low columnar epithelial cells that carry long thin microvilli (brush border) arising from their apical surfaces. The distal convoluted tubules are lined by cuboidal epithelial cells with no brush borders but a few short microvilli and the basal membrane infoldings are highly developed than those of the proximal tubules (Fig. 27). The collecting tubules are lined by low cuboidal or tall columnar epithelial lining cells of variable sizes (Fig. 28).

\section{II-Plant treated groups}

Kidney tissues of rats treated with the plant extract for 15 days showed more or less normal renal corpuscles. The glomerular capillaries contained blood cells. The nuclei of the mesangial cells showed fusion of the nuclear membranes and peripherally accumulated heterochromatin (Fig. 29).

The epithelial lining cells of the renal tubules showed some pathological changes. The epithelial cytoplasm of the proximal tubules contained numerous vacuoles. The Mitochondria were packed with moderate electron dense materials and few lysosomes were identified (Fig 30).
The epithelium cytoplasm of the distal convoluted tubules contained numerous small vesicles, vacuoles, lysosomes (Fig. 31). Moreover, the basement membrane and the basal membrane infoldings were obviously clear and revealed intact appearance (Fig. 31). The intertubular blood capillaries packed with numerous erythrocytes and flocculent materials (Fig. 31).

In rats treated with Cleome droserifolia extract for 30 days, the glomerular capillaries were severely dilated (Figs. 32, 33), the reason for which they obliterated the urinary spaces. The capillary lumen contained numerous erythrocytes and flocculent materials (Figs. 32, 36). Irregular shaped glomerular capillaries were also recorded at figure (36). The nuclei of the mesangial cells (Fig. 33) and the endothelial cells of the glomerular capillaries (Fig. 36) showed clumped heterochromatin. The parietal cells (Fig. 32) were also degenerated and appeared to contain ruptured cell membrane and many non identified cell organelles intermixed with numerous cytoplasmic vacuoles. The parietal (Fig. 32) and mesangial nuclei (Fig. 33) demonstrated fused nuclear membranes and clumped nucleoplasm.

The pathogenesis displayed by the proximal convoluted tubules included severely swollen and injured epithelial lining cells (Figs. 34, 37). The cytoplasm of the tubular lining epithelial cells contained irregular vacuoles and numerous small vesicles (Fig. 34). Some cells lost the electron density of their cytoplasmic components (Fig. 34). Moreover, the mitochondria exhibited slightly swollen appearance (Fig. 34) or swollen configuration with ballooned cristae (Fig. 37).

The lysosomal structures were common within different tubular lining epithelial cells (Figs 37, 38). The nuclei 
appeared with peripherally clumped heterochromatin (Fig. 37).

The distal convoluted tubules were lined by swollen tubular epithelial lining cells (Figs. 35, 38). The cytoplasm of the tubular epithelial cells contained numerous small vesicles, vacuoles of variable sizes (Fig. 38) and some lysosomes (Figs. 35, 37). The lumina of some tubules were occupied by extruded cell organelles, small vesicles and numerous irregular vacuoles (Fig. 38).

The epithelial lining cells of the collecting tubules contained dark mitochondria, numerous vacuoles, small vesicles and lysosomes (Figs. 35, 39). The nuclei revealed irregular nuclear membranes and nucleoplasm (Fig. 39). The basement membranes of some tubules were thicked at some points (Figs. 39).

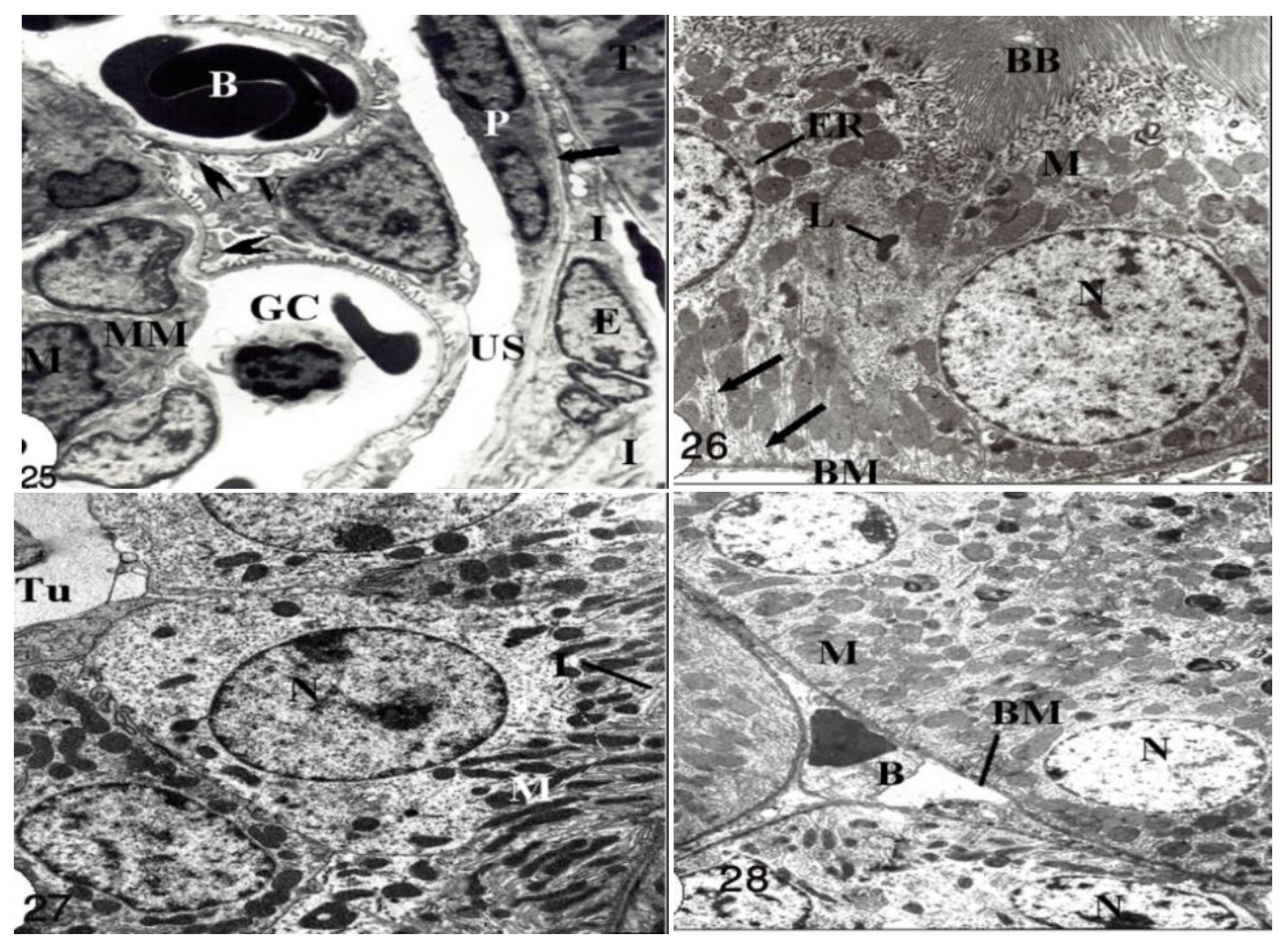

Figure (25): A renal corpuscle of a control rat showing the typical ultrastructure of the Bowman's capsule and the glomerulus. The glomerular capillaries (GC) are lined by fenestrated endothelial cells and contained some blood cells (B). The parietal cells (P) consist of simple epithelia lying on a continuous basement membrane (arrow). The visceral cells (V) are reflected on the glomerular capillaries and attached to their basement membranes by the pedicles (arrow heads). The mesangial cells (M) lie on a continuous basement membrane and surrounded by extracellular mesangial matrix (MM). US: Urinary space, T: Renal tubule, I: Iintertubular blood capillary lined by intact endothelial cells (E). (X11253).

Figure (26): A portion of the proximal convoluted tubule of a control rat showing the apical brush border (BB) and basal membrane infoldings (arrows). The cytoplasm is abundant and contains mitochondria (M), lysosomes (L) and endoplasmic reticulum (ER). The nucleus (N) is oval in shape with well defined nuclear membranes.

BM: Basement membrane. (X9000).

Figure (27): Electron micrograph of a distal convoluted tubule of a control rat showing elongated mitochondria (M) in between basal membrane infoldings (I) and normal rounded nuclei (N). Tu: Tubular lumen. (X9000).

Figure (28): Electron micrograph of control rat exhibiting the intertubular blood capillary (B) surrounded by three renal tubules where the lower one is a collecting tubule. N: Nucleus. BM: Basement membrane M: Mitochondria. (X9000). 


\section{Nahed Mohamed}
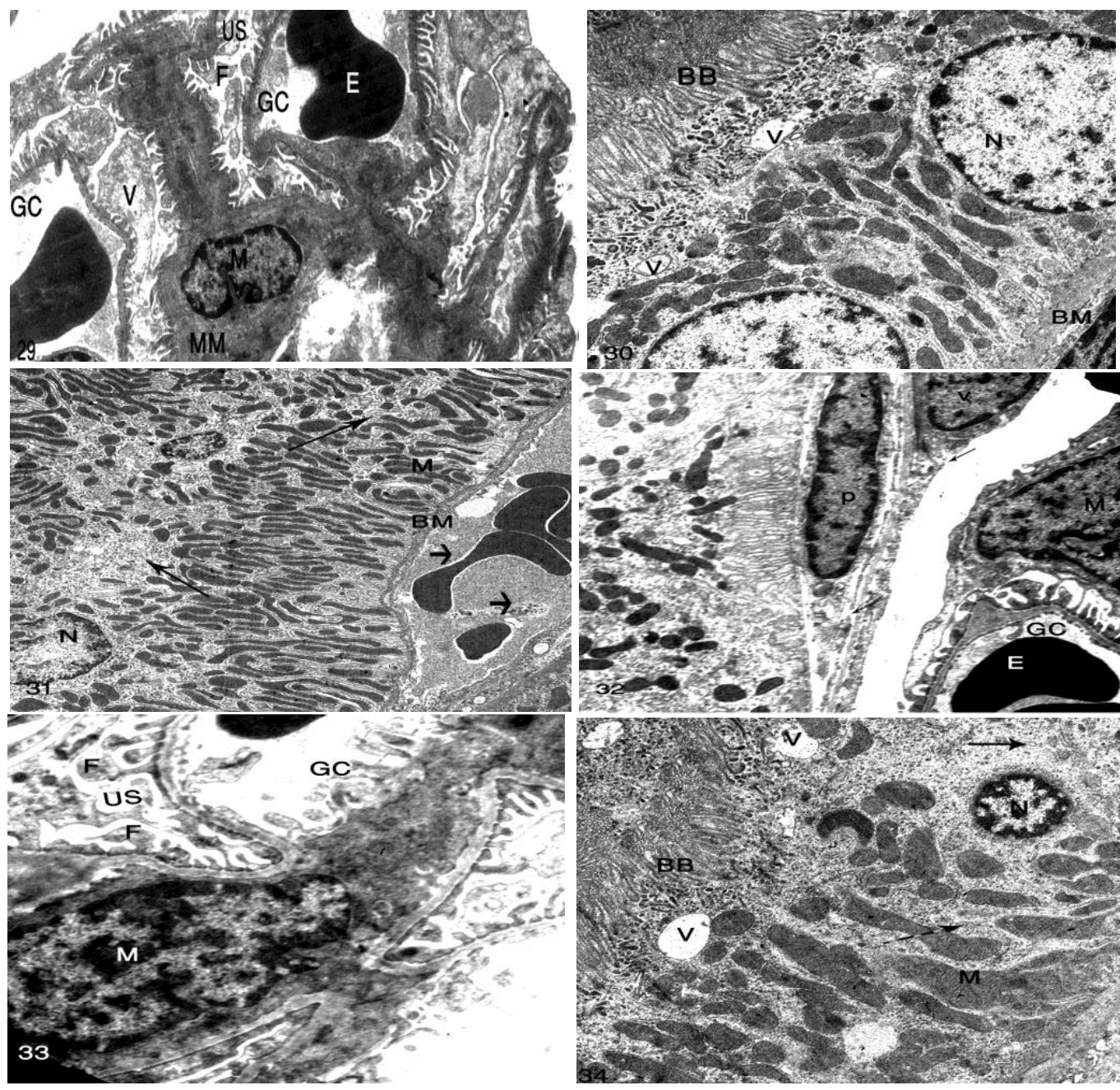

Figure (29): Portion of a renal corpuscle from a rat treated with Cleome droserifolia extract for 15 days showing mesangial cells (M) surrounded by mesangial matrix (MM). The nucleus of the mesangial $(\mathrm{N})$ appeared with peripherally accumulated heterochromatin. US: Urinary space, E: Erythrocyte, F: Foot processes: Visceral cell, GC: Glomerular capillary. (X5293).

Figure (30): Portion of a tubular lining of a proximal tubule from a rat treated with Cleome droserifolia extract for 15 days revealing dark mitochondria (M), dilated brush borders (BB). Note the presence of lysosomal structure (L), cytoplasmic vacuoles (V). N: Nucleus, BM: Basement membrane. (X10587).

Figure (31): Epithelial lining cells of a distal convoluted tubule from a rat treated with Cleome droserifolia extract for 15 days. Note less dense cytoplasm, condensed mitochondria (M), numerous vesicles (long arrows) and nucleus $(\mathrm{N})$. The intertubular blood capillaries packed with numerous erythrocyte and flocculent materials (short arrows). (X5293).

Figure (32): Electron micrograph of a rat treated with Cleome droserifolia extract for 30 days showing portion of a renal corpuscle at the right. Note degenerated epithelia (arrows) and dilated glomerular capillaries (GC). The glomerular lumina contain erythrocytes (E). p: parietal cell, v: visceral cell. (X10587)

Figure (33): Portion of a renal corpuscle from a rat treated with Cleome droserifolia extract for 30 days revealing dilated glomerular capillaries (GC) and mesangial cells (M) with heavy cytoplasm and clumped nucleoplasm. F: Foot processes, US: Urinary space. (X15880).

Figure (34): Portion of a proximal convoluted tubule from a rat treated with Cleome droserifolia extract for 30 days revealing less dense cytoplasm with numerous vacuoles (V), dilated brush borders (BB), small vesicles (arrows) and swollen mitochondria $(\mathrm{M})$. The nucleus $(\mathrm{N})$ appeared with peripherally accumulated heterochromatin. (X10587). 


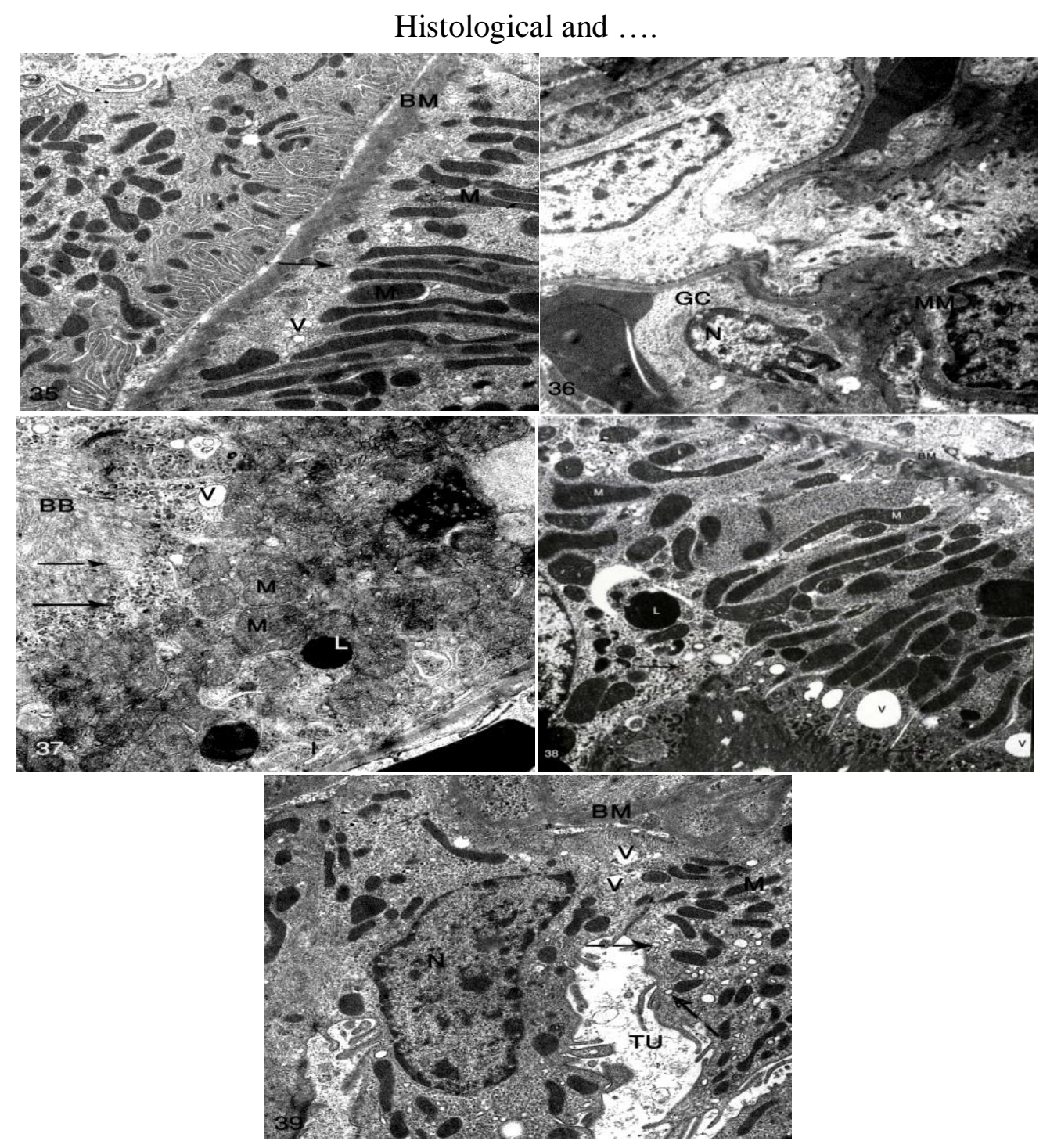

Figure (35): Electron micrograph of a rat treated with Cleome droserifolia extract for 30 exhibiting portion of a distal convoluted tubule at the right and a portion of a collecting tubule at the left side. The epithelial lining cells of the distal convoluted tubule exhibiting less dense cytoplasm with numerous small vesicles (arrows) and vacuoles (V). BM: Basement membrane. (X10587).

Figure (36): Portion of a renal corpuscle from a rat treated with Cleome droserifolia extract for 45 days revealing highly dilated glomerular capillaries (GC) and mesangial cells with heavy cytoplasm surrounded by mesangial matrix (MM). The nuclei of the mesangial (N) and the endothelial cell (n) of the glomerular capillary appeared with irregular nuclear membranes and peripherally accumulated clumped heterochromatin. (X10587).

Figure (37): Swollen epithelial cell of a proximal convoluted tubule from a rat treated with Cleome droserifolia extract for 45 days revealing less dense cytoplasm with swollen mitochondria (M) and ballooned cristae, lysosomal structures (L), cytoplasmic vesiculation (arrows). BB: Brush borders. (X10587).

Figure (38): Epithelial cell of a distal convoluted tubule from a rat treated with Cleome droserifolia extract for 45 days revealing dark mitochondria (M), numerous vacuoles (V), small vesicles (arrows), and lysosomes (L) within the cytoplasm. (X10587).

Figure (39): Epithelial cell of a collecting tubule from a rat treated with Cleome droserifolia extract for 45 days revealing condensed mitochondria (M), cytoplasmic vacuoles (V), small vesicles (arrows), and lysosomes (L) within the cytoplasm. The nucleus showed irregular envelope and clumped marginated heterochromatin. Tu: Tubular lumen, BM: Basement membrane. (X10587). 


\section{Discussion:}

Medicinal plants have been used for centuries in the treatment of many diseases. Consequently, attention has been focused on the use of plants and herbal remedies believed to be safer and devoid of serious side effects as alternatives in treatments. Therefore, the present study investigated the effects of Cleome droserifolia methanolic extract on the liver and kidney tissues of rats for 15, 30, 45 days.

Most reports of toxic effects due to the use of herbal medicines are associated with hepatotoxicity although reports of other toxic effects including kidney, blood, mutagenicity, and carcinogenicity have also been published in medical literatures. Liver injury from herbal remedies has ranged from mild elevations of liver enzymes to fulminated liver failure requiring liver transplantation.

The reported toxicity of herbal formulations may be the result of several factors, including contamination with pesticides, microbes, heavy metals, toxins or adulteration with orthodox drugs (EI Nahhal et al., 2004). Therefore, for safety and quality assurances, chemical analytical techniques should be applied for good practices of herbal products, including good agricultural practice, good sourcing and laboratory practices by pharmaceutical companies (Chan et al., 2003).

In the present study the oral administrations of Cleome droserifolia methanolic extract at $100 \mathrm{mg} / \mathrm{kg}$ induced histopathological changes in a time dependant manner. Whereas with the orally administration for 15 and 30 days produced cellular swelling with cytoplasmic vacuolization and hypertrophied Kupffer cells with necrotic cells. While with the prolonged administration for 45 days the changes increased in severity and showed increased necrotic cells with pyknotic nuclei and the blood vessels were engorged with blood.
El Zorba (1993) studied the histopathological changes Cleome droserifolia alcoholic extract and revealed only dilatation of blood vessels with karyomegalic nuclei as well as activation and proliferation of Kupffer cells. Moreover, oral administration of the aqueous extract of Cleome droserifolia to rats showed histologically disturbed arrangement in liver cords and congestion of the central vein in the liver and there are large population of cells with Kupffer cells and endothelial cells as reported with Helal et al. (2002)

As observed in this study, the increased Kupffer cells population may indicate active role of these cells in phagocytosis of RBCs which is normally met with in cases of iron deficiency (Nicolas et al., 2002). Also Cleome droserifolia extract causes iron deficiency and produced significant decrease in RBCs and heamoglobin and these results may be lead to signs of anemia of treated animals as showed by Helal et al. (2002). In hepatocyte cultures, extracts of Cleome droserifolia were found to affect the cell viability (Saad et al., 2006).

On the other hand, Alqasoumi (2007) proved the hepatoprotective properties of Cleome droserifolia plant extracts from Saudi Arabia against liver toxic substance, carbon tetrachloride. Also Abdel-Kader et al. (2009) proved the hepatoprotective properties of Cleome droserifolia plant against carbon tetrachloride induced liver injury through biochemical parameters and histopathological analysis. The authors also isolated the hepatoprotective constituents from the plant whereas the petroleum ether fraction afforded guaiane sesquiterpenes, buchariol, teucladiol in addition to daucosterol and The $\mathrm{CHCl}$ fraction afforded three known flavonoid derivatives.

The disagreement in results may be attributed to the differences in the species obtained from different localities or to difference in route of administration or to 
the differences in the extract type of the plant used.

At the ultrastructural level, the present study showed numerous changes in the hepatic cells in rats treated with Cleome droserifolia extract especially with 30 , 45days such as the presence of patches of glycogen depletion within the hepatic cell cytoplasm. This result could be confirmed by those obtained by many investigators who reported that Cleome droserifolia plant act as hypoglycemic or antidiabetic plant (El Naggar et al., 2005; El-Shenawy and Abdel-Nabi, 2006). The depletion of liver glycogen stores in rats could be due to the loss of glycogen synthetase-activating system and/or increased activity of glycogen phosphorylase (Abdel-Moneim et al. 1997; El-Shenawy and Abdel-Nabi, 2006).

The observed numerous cytoplasmic vacuoles in the hepatic cell cytoplasm were also reported by Khleifat et al. (2002) in case of treatment with Teucrium polium extract. Similar results were reported by Du Plessis (2005) in the electron microscopical studies on the hepatocytes of cattle treated with Nolletia gariepina plant (Asteraceae) and Mansour (2008) on the hepatic cytoplasm of rats treated with Ambrosia maritima extract for 45 days. The appearance of condensed mitochondria and swollen endoplasmic reticulum were reported with other investigators. Barbosa-Ferreira et al. (2005) showed that the treatment with Senna occidentalis plant revealed mitochondrial lesions in liver cells of treated rats.

In accordance with the present studies the abnormalities of the hepatic nuclei were also reported by Du Plessis (2005) in the hepatiic cells of animals treated with Nolletia gariepina plant. Williams et al. (2000) reported that, the intact appearance of the plasma membrane of the hepatocyte of plant treated animals is important in maintaining the ion balance between the cytoplasm and the external environment. Loss of ionic control can cause a net movement of water into the cell, resulting in cell swelling.

In the present study examination of the renal tissues from rats administrated orally with Cleome droserifolia methanolic extract induced histopathological changes in a time dependant manner whereas, glomeruli changes and tubular lesions were increased in severity at the 45 days of treatment. The glomeruli were hypertrophied with thickening of Bowmen's capsule and the renal tubule exhibited severe cytoplasmic vaculation and damaged epithelial lining cells with pyknotic nuclei. In addition there are many inflammatory cells invading the intertubular spaces.

In accordance with the present study Oldele and Abatan (2003) the histopathological changes of the kidney of rats treated with leaves aqueous extract of Cleome viscosa plant for 28 days showed generalized nephrosis of the tubular epithelial cells thus the effect of this plant may mean it is nephrotoxic.

At the electron microscopic levels, the present study showed many ultrastructural changes in both renal corpuscles and tubules in kidney tissues of rats treated with Cleome droserifolia extract for 30 and 45 days.

Du Plessis (2005) reported that the examination of the glomeruli of animals treated with Nolletia gariepina plant (Asteraceae) did not reveal any abnormalities. The presence of increased numbers of cytoplasmic vacuoles in the ultrastructural sections of the renal tubules of rats after chronic treatment with Teucrium polium and Ambrosia maritima plants (Asteraceae) was reported by Khleifat et al. (2002) and Mansour (2008) respectively.

Moreover, the observed increase in the number of lysosomes as well as chromatin margination in the form of irregular clumps along the inner membrane of the nuclear envelope were also observed in the proximal convoluted tubules in 
animals treated with Nolletia gariepina plant (Du Plessis, 2005).

Despite the slight changes of the basement membrane and plasma membranes of the present kidney sections in plant treated rats, Du Plessis (2005) showed that the treatment with Nolletia gariepina plant (Asteraceae) induced loss of the cell membrane of the tubular lining epithelial cells of the proximal tubules accompanied with dispersed internal cytoplasmic organelles, nuclear disorganization and disappearance of the brush border. In the present study the mitochondrial swelling observed in kidney sections of plant treated rats were also reported by Barbosa-Ferreira et al. (2005) in rats treated with Senna occidentalis seeds.

In contrast with the present study, Mansour (2008) reported slight ultrastructural changes in the epithelial cells of the proximal and distal convoluted tubules obtained from rats treated with Ambrosia maritima plant for 45 days. The author added that all cytoplasmic organelles appeared minimally affected and most of the nuclei had normal chromatin dispersion.

Such changes induced as a result of plant treatment in the present study may be due to toxic effect or accumulation of one or more of the active pharmacological compounds of the plant in the liver or kidney tissues of treated rats (Haggag, 2000). These compounds include quercetin, kaempferol, isorhamnetin, terpenoids, glycosidic flavonoids, coumarins and phenolic acids which were isolated or identified from Cleome droserifolia plant (Fushiya et al., 1999; El Naggar et al., 2005; El-Askary, 2005). Flavonoids are major functional components of many herbal preparations for medical use, therefore modern authorized physicians are increasing their use of pure flavonoids to treat many important common diseases, due to their proven ability to inhibit specific enzymes, to simulate some hormones and neurotransmitters (Havsteen, 2002).

\section{References:}

1. Abdel-Kader M S, Alqasoumi, S I and AlTaweel A M (2009): Hepatoprotective constituents from Cleome droserifolia. Chem. Pharm. Bull (Tokyo); 57(6):620-624.

2. Abdel-Moneim A, El-Feki M and Salh E (1997): Effect of Nigella sativa, fish oil and gliclazide on alloxan diabetic rats. 1Biochemical and histopathological studies. J. Egypt Ger., 23:237-265.

3. Aboushoer M I, Fathy H M, Abdel-Kader M S, Goetz G and Omar A A (2010): Terpenes and flavonoids from an Egyptian collection of Cleome droserifolia. Nat. Prod. Res. , 24 (7):687-696.

4. Alqasoumi S I (2007): Isolation and chemical structure elucidation of hepatoprotective constituents from plants used in traditional medicine in Saudi Arabia. Ph D in Science. Dep. of Pharmacognosy, Pharmacy collage, King Saud University.KSA

5. Ammar N M, Al Okbi S Y and Badawy $\mathrm{H}$ (1993): The hypoglycemic effect of different extracts of Ambrosia maritima, Compositae. J. Islamic Acad. Sci., 6(4): 298-301.

6. Bala A, Kar B, Haldar P K, Mazumder U $\mathrm{K}$ and Bera, S (2010): Evaluation of anticancer activity of Cleome gynandra on Ehrlich's Ascites Carcinoma treated mice. J. Ethnopharmacol., 129 (1): 131-134.

7. Barbosa-Ferreira M, Dagli M L, Maiorkab P C and Gorniak S L (2005): Sub-acute intoxication by Senna occidentalis seeds in rats. Food Chem. Toxicol. ${ }_{2} 43(4)$ : 497-503.

8. Bose A, Mondal S, Gupta J K, Ghosh T and Dash G K (2007): Analgesic, antiinflammatory and antipyretic activities of the ethanolic extract and its fractions of Cleome rutidosperma. Fitoterapia, 78(7-8):515-520.

9. Boulos L (1995): "Flora of Egypt Chicklist." AL. Hadara Publishing, Cairo, Egypt, pp. 168, 169, 567 and 568.

10. Boulos L (1999): "Flora of Egypt, Azollaceae and Oxalidaceae".,Vol. 1, AL Hadara Publishing, Cairo, Egypt, pp. 177-180.

11. Bouriche, H and Arnhold J (2010): Effect of Cleome arabica leaf extract treated by naringinase on human neutrophil chemotaxis. Nat. Prod. Commun. ; 5(3):415-418.

12. Chan K. (2003): Some aspects of toxic contaminants in herbal remedies. A review. Chemosphere, 52:1361-1371.

13. Devi BP, Boominathan R and Mandal SC. (2002): Evaluation of anti-diarrheal activity of Cleome viscosa L. extract in rats. Phytomedicine, 9(8):739-742. 
14. Du Plessis E C (2005): Pathological investigation of the nephrotoxic effects of the shurp Nolletia gariepina (DC) Mattf in cattle. M.Sc. Thesis. Paraclinical Science Department, Faculty of Veterinary Science, Pretoria etd University. South Africa.

15. Drury R and Wallington E (1980) Carlton's Histological Techniques. Fifth edition Oxford University Press, New York.

16. El Naggar E M.B , Bato-Kov L, Emliaka M, Vajdlenka E, Rabi- Kov V Satrnadov V and Neaas J (2005) : Antidiabetic effect of Cleome droserifolia aerial parts: Lipid Peroxidation-induced oxidative stress in diabetic rats . Acta. Vet. Brno., 74: 347-352. 17. El Nahhal Y (2004): Contamination and safety status of plant and food in Arab countries. J. Appl Sci., 4:411-417.

18. El-Askary, H I (2005): Terpenoids from Cleome droserifolia (Forssk.) De. Molecules; 10 (8): 971-977.

19. El-Shenawy N S and Abdel-Nabi I M (2006): Hypoglycemic effect of Cleome droserifolia ethanolic leaf extract in experimental diabetes and on non -enzymatic antioxidant glycogen, thyroid hormone and insulin levels. Diabetologia Croatica ; 35 (1) $: 15-22$.

20. El-Shenawy N S, Soliman M F and AbdelNabi I M (2006): Does Cleome droserifolia have anti-schistosomiasis mansoni activity? Rev. Inst. Med. Trop. Sao. Paulo. , 48(4):223228.

21. El-Zorba H (1993). "Pharmacotoxic studies on Cleome droserifolia and Centaurium spicatum herbs used in folk medicine". M. Sc. Thesis, Faculty of Science. Cairo University. Giza, Egypt.

22. Fushiya S, Kishi Y, Hattori K, Batkhuu J, Takano F, Singab A N and Okuyama T (1999). Flavonoids from Cleome droserifolia suppress no production in activated macrophages in vitro. Planta Med., 65(5):404 - 407.

23. Gupta N K and Dixit V K (2009): Evaluation of hepatoprotective activity of Cleome viscosa Linn. extract. Indian J .Pharmacol., 41(1):36-40.

24. Haggag E I (2000): Phytochemical studies on some Egypian plants related to families Compositae and Ranunculaceae. Ph.D. Thesis, Faculty of Science. Cairo University, Giza, Egypt.

25. Havsteen H B (2002): The biochemistry and medical significance of the flavonoids. Pharmacology \& Therapeutics, 96 (2-3): 202 267.
26. Hayat M A (1989): "Electron Microscopy, Biological Applications" 3rd ed., MacMillan Press, Ltd., London.

27. Helal I G, Sharaf H A and Matter F E (2002): Anti-diabetic and anti-obesity effects of plant extract from Cleome droserifolia (Samwa). Egypt. J. Hosp. Med., 9: 85-101.

28. Karnofsky M J (1965): A formaldehydeglutaraldehyde fixative of high osmolarity for use in electron microscopy. J. Cell Biol., 27: 137-138

29. Khleifat K, Shakhanbeh J and Tarawneh K (2002): The Chronic effects of Teucrium poliumon on some blood parameters and histopathology of liver and kidney in the rat. Turk. J. Biol., 26: 65 -71

30. Mansour N M (2008): Histological and cytogenetic studies on the effect of Ambrosia maritima plant from Sinai on different tissues of rats envenomed with Leiurus quinquestriatus scorpion. Ph.D. Thesis, Zoology Department, Faculty of Science.Suez Canal University, Ismailia, Egypt.

31. Mikhail Y A (2000): Studies on the hypoglycemic effects of Cleome droserifolia and bran of Triticum vulgaris. M.Sc. Science. Faculty of Science. Cairo University. Egypt.

32. Narendhirakannan R T, Subramanian $S$ and K and Aswamy M (2006): Anti-inflammatory and lysosomal stability actions of Cleome gynandra L. studied in adjuvant induced arthritic rats. Food Chem .Toxicol., 45(6):10011012 .

33. Nicolas G, Chauvet C, Viatte L, Danan J L, Bigard X, Deveux I, Beaumont C, Kahan A and Vaulont S (2002): The gene encoding the iron regulatory peptide hepcidin is regulated by anemia, hypoxia and inflammation. J. Clin. Invest. , 110 (7): 1037-1044.

34. Oladele G M and Abatan M O (2003): Histopathological and serum biochemical changes following oral administration of aqueous crude extracts of Hyptis suaveolens, Urena lobata and Cleome viscosa in rats. Trop. Vet., 22(1): 9-15.

35. Reynolds E S (1963): The use of lead citrate at high $\mathrm{pH}$ as an electron opaque stain in electron microscopy. J. Cell Biol., 17: 208-212.

36. Rizk A M (1986): 'The Phytochemistry of the Flora of Qater M.Sc. Department of Chemistry, Faculty of Science. University of Qater. pp. 39-51.

37. Saad B, Dakwar S, Said O, Abu-Hijleh G, Al Battah F, Kmeel A and Aziazeh H (2006): Evaluation of medicinal plant hepatotoxicity in co-cultures of hepatocytes and monocytes. Evid Based Complement Alternat. Med., 3 (1):93-98 


\section{Nahed Mohamed}

38. Sudhakar M, Rao Ch V, Rao P M and Raju D B (2006): Evaluation of antimicrobial activity of Cleome viscosa and Gmelina asiatica. Fitoterapia. ; 77 (1):47-49.

39. Tackholm V (1974): "Students Flora of Egypt". $2^{\text {nd }}$ ed. Publisher Cairo University, Cooperative printing Co., Egypt.

40. Thomas L S (2000): "Medicinal Plants, Culture, Utilization and Pharmacology". Technomic Publishing Co. Inc., Lancaster, Basel. pp. 20-55.

41. Weiss S and Fintelmann V (2000): Herbal Medicine. $2^{\text {nd }}$ ed. Theieme medical publisher, New York.
42. Williams L A, Vasques E, Reid W, Porter $\mathrm{R}$ and Kraus W (2003): Biological activities of an extract from Cleome viscosa L. (Capparaceae). Naturwissenschaften.; 90 (10):468-472.

43. Williams P L, James R C and Roberts S R (2000): Principles of Toxicology. Environmental and Industrial Applications". 2nd ed., Wiley-Interscience Publication, NewYork, pp. 111-432.

44. Zaohkouk S M, Helal E and Rashed S M (2001): Effect of the extract of Cleome droserifolia (Samwa) on some physiological parameter in streptozotocin diabetic rats. Al Azahr University Bull. Sci. ,12(2):93-107.

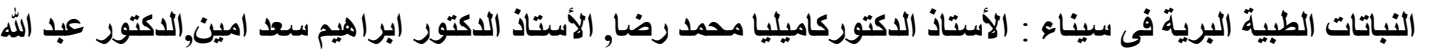

الطبعة الأولى - مؤسسة الخليج العربى - القاهرة (2000). 


\title{
دراسات هستولوجية وخلوية دقيقة عن تأثير نبات الصموة من سيناء على أنسجة الكبا والكلية للجرذان
}

\author{
ناهد محمد منصور امام \\ قسم العلوم البيولوجية والجيولوجية كلية التربية جامعة قناة السويس
}

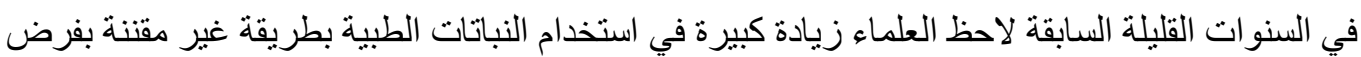

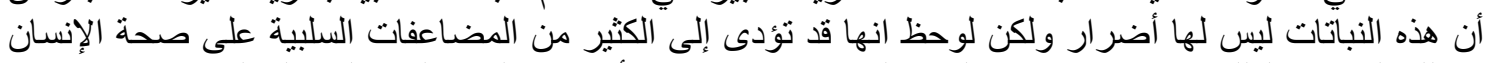

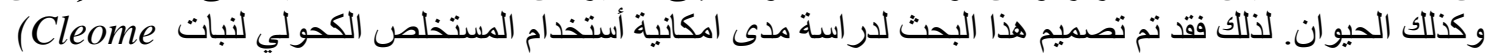
droserifolia)

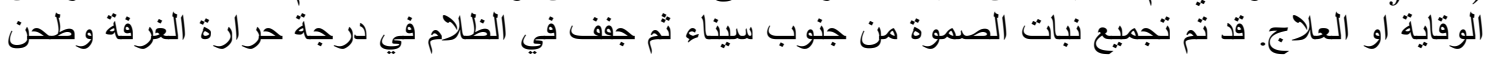

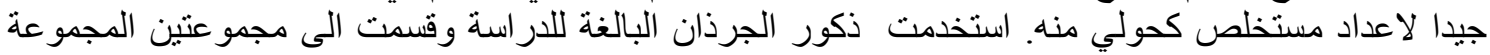

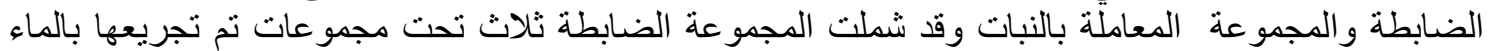

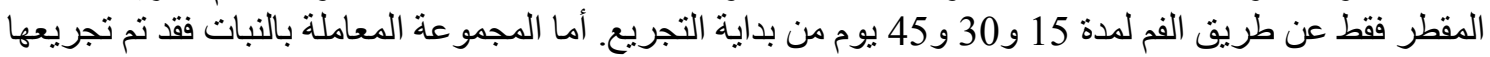

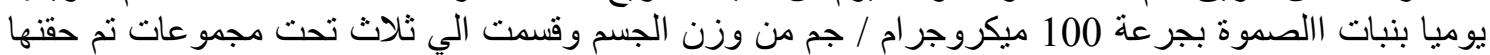
عن طريق الفم بالمستخلص الكحولي للنبات لمدة 15 و30 و 45 يو وزن الجن من بداية التجريع على الترنيب.

وبعد مرور الفترة الزمنية المخصصة لكل تحت مجموعة نت تشريح عشرة جرذان من كل مجموعة الأكئ

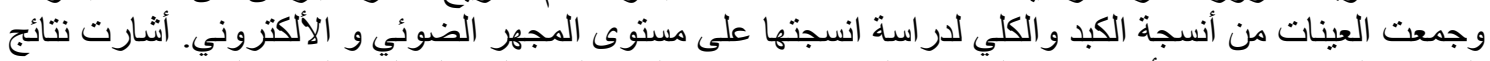

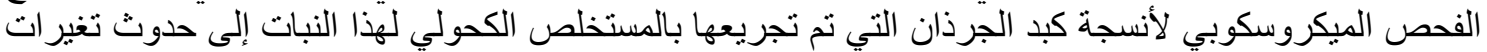

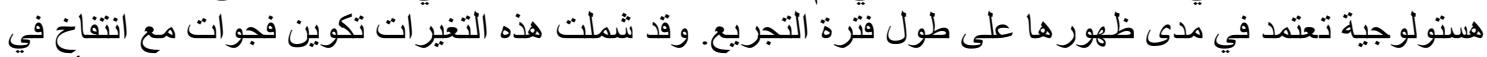

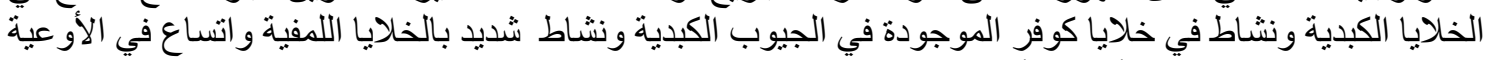

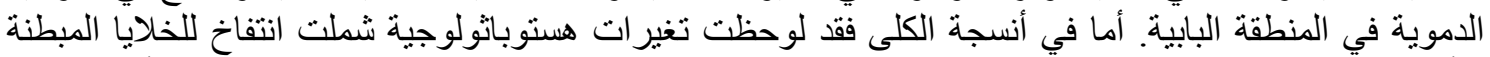

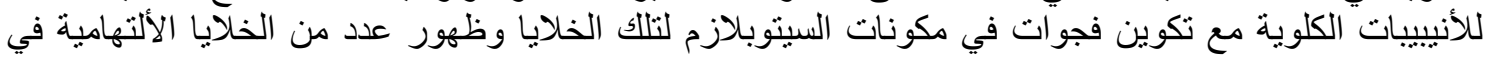
المسافات بين الانيبييات.

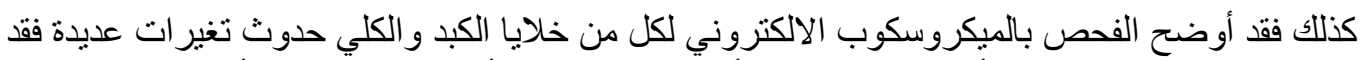

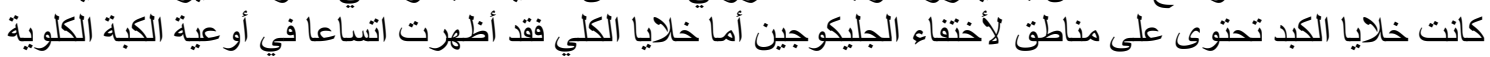

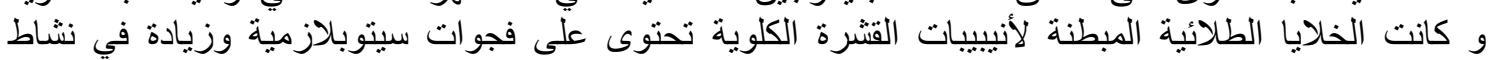
الليسوزومات.

نستتنج من هذة الدراسة إن استخدام مستخلص نبات الصموة قد يؤدى الى العديد العديد من التغيرات الهيتولوجية والخلوية الدقيقة التى تزداد فى حدتها مع زيادة فترة التجريع.

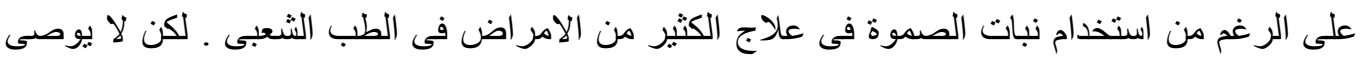

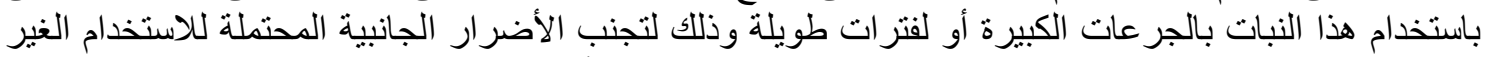

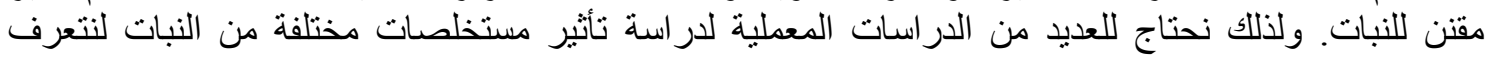

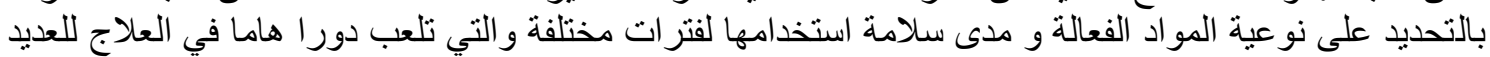
من الأمر اض دون حدوث أثنار جانبية. 